\title{
Missio Dei perspectives in the Canons of Dort
}

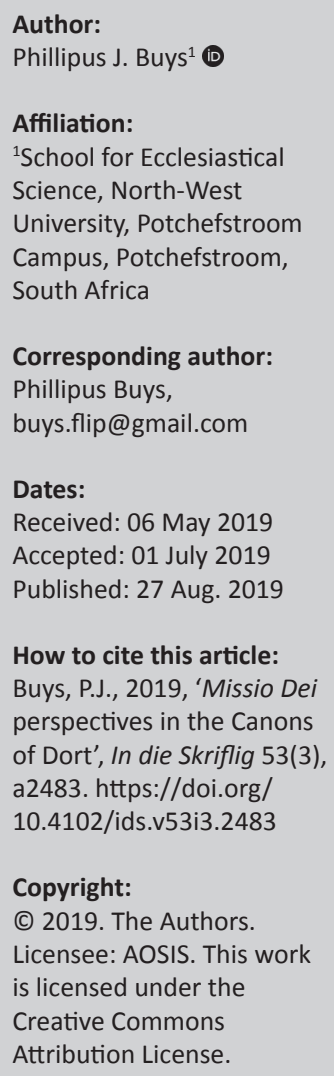

Reformed churches around the world are commemorating the 400th anniversary of the Synod of Dordtrecht in the Netherlands and its global impact. The Canons of Dort, or Canons of Dordtrecht, formally titled The decision of the Synod of Dort on the five main points of doctrine in dispute in the Netherlands, is the judgement of the National Synod about the five points of the Remonstrants held in the Dutch city of Dordtrecht in 1618-1619. Before and after the Synod of Dort the complaint has often been raised that the Reformed doctrines of predestination and election have produced churches and Christians who have very limited passion or no zeal at all for the church's call to missions. People who hold negative ideas about reformed spirituality often used the derogative of the 'frozen chosen' to express the idea that the Reformed faith inevitably suffocates vital spirituality, evangelistic outreach, church planting, and missions. The claim is made that this alleged neglect is caused by the Reformed doctrine of election. A sentiment exists among some missiologists that confessionally Reformed believers are not enthusiastic about sharing the gospel of Christ with those who are strangers to the gospel of Christ and Christianity. But is this true of the Canons of Dort, that was one of the main outcomes of the Synod of Dort? Some researchers even express the opinion that the Canons being produced by this Synod of Dort have the most outspoken mission statements of the three reformed confessions. This article endeavours to open a window on the synod's deliberations with the Remonstrants to highlight missional perspectives when the background and main emphases of the canons are examined. Special attention on how biblical piety, missional spirituality and its implications for the missio Dei in practice may be observed in the history before after and during the Synod of Dort and in key sections in the Canons of Dort. The practical implications of these perspectives will also be considered.

Keywords: Canons of Dort; Missio Dei; Predestination; Election; Hyper-Calvinism; Free offer of the Gospel; Remonstrants; Gisbertus Voetius; 'Easy-believism'.

\section{Are the Canons of Dort relevant after $\mathbf{4 0 0}$ years?}

Dr Suzanne McDonald, in her lecture at a Synod of Dort Conference at the Calvin Seminary in Grand Rapids during September 2018, expressed the opinion that it often seems like the Canons are the most neglected in our congregations and by our churches.

In a survey she did among seminary students she came to the findings that approximately $80 \%$ haven't read the Canons, but they are convinced it is an unequivocally terrible document, and that they will hate it. Approximately 20\% haven't read the Canons, but they are prepared to defend them to the death as the foundation and summary of all Reformed theology (McDonald 2018).

Huijgen (2018:113) convincingly argues that some emphasis of the Canons, which combine the denial of human autonomy as decisive for regeneration and real human responsibility, predestination, and a contingent (unnecessary) reality, are even more relevant today than in the 17th century. According to his analysis the fronts have shifted: while the Reformed were under suspicion of determinism in early modernity, neuroscience in the postmodern era presents a form of determinism that Reformed people will wish to refute.

Coetzee (2018:1) expresses the opinion that the Synod of Dort and the decisions taken there are still relevant today as far as the contents of the decisions of Dort is concerned.

In his latest book recently published after a lifetime of study and research on the Synod of Dort, Robert Godfrey (2019) writes:

The Synod of Dort (1618-19), the greatest of the Reformed church assemblies, preserved the great heritage of the Reformation for the Calvinistic churches. (p. 1) 
De Jong (2008:11) has the conviction that although the configurations of today's crisis in the church and world differ from those of the days of Dort, the underlying issues remain remarkably similar.

On the relevance of the Canons of Dort for missions and evangelism, it seems that little has been published and it seems that there is still widespread suspicion in some quarters that faith in the absolute sovereignty of God hinders a full recognition and acceptance of evangelistic responsibility.

Haak (2016:23) expresses the opinion that the Canons being produced by the Synod of Dort, have the most outspoken mission statements of the three reformed confessions.

This article offers a rereading of the Canons in the light of the present-day challenges encountered in global mission, intending to point out the relevance of key aspects of the pastoral theological perspectives in the Canons for the practice of the current day-missional outreach of God's people providing the vision, strength, and perseverance that is needed for churches to be missional churches.

\section{Missional relevance of Dort}

Several scholars expressed the idea that Calvin's doctrine of predestination revenged itself in reformed mission theology and the lack of a clear vision for missions. As Bredenhof (2014) formulates: 'There are those who say that election knocks the motivation out of outreach'.

In similar way, Stewart (2009:64) indicates that churches standing in the Reformed theological tradition have regularly been suspected of constituting a 'weak link' in support for world missions and evangelism. He points out that Reformed theology's endorsement of the doctrine of predestination has been singled out by non-Calvinists to provide a kind of respectable subterfuge for lethargy in missions and evangelism.

On the contrary, research has demonstrated the presence in the Synod of Dort (1618-1619) of advocates of foreign missionary work such as Gisbertus Voetius, and of language in the Canons of Dort that was supportive of the missionary task.

In quite a few textbooks of the church growth movement, 'predestinarianism' is blamed for the lack of a zeal for missions at the times of the Reformation and in the circles of reformed type churches (Conn 1976:25; cf. also Buys 1988:87ff.).

In this regard Haak (2016) formulated McGavran's challenge as follows:

It was a both embarrassing and challenging question of Donald McGavran at the very start of a mission study conference with a lot of reformed missionary participants: 'Please, can you indicate to me the passages about the missionary mandate and its ecclesial implications in your three Reformed Confessions?'
The silence in the class room was audible as many quickly scanned their beloved creedal documents. Several minutes later the shameful answer became evident. No one could point to a kind of mission-minded command, clue or structure. So, pleasing the McGavran's expectation, the stage was set: Reformed confession completely lacks missionary content, flavour, and motivation. (p. 3)

On the other hand, hyper-Calvinistic trends indeed became the attitude of some Calvinists. In short, hyper-Calvinists deny that non-Christian hearers is responsible to repent and believe the gospel (Fuller 1837; Storey 2018:1; for a different opinion on hyper-Calvinism, cf. also Engelsma 1980). ${ }^{1}$

A hyper-Calvinistic trend did surface among reformed people in the Netherlands and South Africa. Here are some examples:

When the first minister of the Reformed Churches in South Africa, Rev. Dirk Postma in 1860-1870 launched strong appeals that the Reformed Churches should get more involved in practical mission projects and the synod decided in 1869 that churches should pay serious attention to their missionary mandate, a brother Coetzee from Redderburg, stimulated by Rev. S.D. Venter, expressed a kind of fatalistic mission theology, saying that we should wait that the Lord first work in the midst of the non-white people and then we should follow. Behind this reasoning was the whole theology of the Drendt trend among the Secession churches (Afscheiding) in the Netherlands (Veenhof 1959:45-57, 88-131). This theology that was embraced by Rev. S.D. Venter and quite a substantial group within the Reformed Churches in South Africa, taught that certain signs of God's preparational grace must first be seen in the lives of people as an indication of God's elective grace, before a well meant offer of the promises of the gospel may be presented to them. S.D. Venter and others expressed the opinion that no signs of this preparational grace had surfaced among the non-white people groups yet. Therefore, there are no mandate of God to the Reformed Churches to embark on missions among the nonwhite population of the country (Van der Vyver 1958:394-418; Van der Waal 1983:44-52; cf. also Van Ryssen 1983:3 who gave historical proof that today there are still some hyper-Calvinistic trends among some theologians in the RCSA churches).

I.J. van der Walt (1982:5), who serve as professor of Missiology at the seminary of the RCSA churches in Potchefstroom rightly warned: "n Eensydige selfgerigte introverte verkiesingsbegrip lei tot traagheid en belangeloosheid oor die lewe en lot van ander verbondskinders'.

It is noteworthy that Arminius and the Remonstrants in their The five articles of the Remonstrants (1610; cf. Bratcher 2018; cf. also Jackson 1914:482) accused the Reformed people of determinism. When preaching on the first chapters of Romans, Arminius on more than one occasion ironically

1.In an article about James Durham and the Free offer of the Gospel, Maclean (2010:94) points out that the free offer of the gospel was not only a source of dispute in centuries past but that recent literature provides clear evidence that the dispute in centuries past but that recent literature provides clear evidence that the gospel offer is currently a source of controversy within some Reformed churches. He then refers to Herman Hanko's The history of the free offer, David Engelsma's HyperCalvinism and the call of the gospel, and George Ella's The free offer and the call of the gospel. This debate is not confined to these stand-alone volumes but is also found in more general works. For instance, Robert Reymond's Systematic theology criticises John Murray's position on the free offer of the gospel but Scott Clark's (2018) essay in The pattern of sound doctrine argues Murray's position is scriptural. 
remarked that his hearers would have done better to remain in the Roman Catholic Church, because then at least they would be doing good works in the hope of eternal reward, while now they did none at all (Praamsma 2008:45). When his colleague in the church in Amsterdam accused Arminius of Socinian opinions, he revealed his doubts concerning article 16 of the Belgic Confession.

In his writings, Arminius often repeated biting criticism, that unconditional predestination logically makes God the author of sin. He vehemently rejected supralapsarianism by stating that supralapsarianism is 'a perversion of the gospel of Christ' and 'the subversion of the "foundation of religion in general, and of the Christian religion in particular"', 'is inspired by Satan and is a doctrine quite compatible with the kingdom of darkness'. But several researchers indicated that supralapsarianism was only held by a small minority group among the Calvinists at Dort. ${ }^{2}$

Considering the missional perspectives in the Canons of Dort, it provides a tertium quid - a third way - between the Scylla and Charybdis of Arminianism and hyperCalvinism.

\section{Brief historical perspectives}

One can only understand a creedal document when one knows the circumstances under which it came into existence. The Synod of Dort (1618-1619) was convened in order to settle a serious controversy in the Dutch churches initiated by the rise of Arminianism. ${ }^{3}$ After Arminius's death, 43 of his ministerial followers drafted and presented their views to the States General of the Netherlands on five points in a Remonstrance of 1610. The 'Remonstrants', taught:

1. Election based on foreseen faith.

2. The universal merits of Christ.

3. The free will of man due to only partial depravity.

4. The resistability of grace.

5. The possibility of a lapse from grace.

They desired the Reformed church's doctrinal standards to be revised and their own views to be accepted and protected by the government. The Arminian-Calvinism conflict became so severe that it led the Netherlands to the brink of civil war. Finally, in 1617 the States General voted to call a national Synod to address the views of the Remonstants. It was particularly felt that the Arminians, or Remonstrants (as they were then called), failed to do justice to the spiritual inability of fallen man and to the sovereignty of God in the work of saving man from sin. It was in response to these erroneous teachings that the Synod of Dort drew up its canons, under five heads of doctrine.

2.For an in depth discussion of Arminius theological development, cf. Godfrey (2019:185-228); Meijerink (1965:7-65); Praamsma 2008); Stanglin (2019); and Stanglin and McCall (2012.

3. Recently many authors described the historical background that led to the Synod of Dort. Within the focus and delimitation of this article it is not possible or necessary to summarise what several authors have already published about the historical to summarise what several authors have already published about the historical
context of the Synod of Dort. It is sufficient to refer to Coetzee 2018; Faber et al. 1965; Godfrey 2019; Muller 1991; Van den Brink 2017; and Verboom 2005.

\section{The Covenant of redemption and missio Dei foundation in the theology subjacent to the Canons of Dort}

To understand the missio Dei perspectives inherent in the Canons of Dort, it is important to also consider theological trends before, during and after the synod among Reformed theologians in the Netherlands. The Canons stress that the process of reconciliation between the Triune God and man is primarily and in whole the work of God - from its beginning in God's pretemporal decree to its consummation in eternity. We could therefore agree with Hoekema and Haak that the main focus of the Canons is on the missio Dei [the mission of God]: God's redemption of the cosmos through the saving work of Jesus Christ, applied to the hearts of his people by the Holy Spirit (Haak 2016:6; Hoekema 1972:2010). This reasoning is affirmed when it is considered that the missio Dei is rooted in the covenant of redemption (pactum salutis).

The Latin term, missio Dei, was coined already in the fourth century a.d. by Aurelius Augustinus to describe the sending acts within the Trinity, i.e. God the Farther sending Jesus Christ the Son of God. From then on missio Dei became a major term in Catholic and Orthodox dogmatics (Müller 1985:57-59; Schirrmacher 2017:7).

In explaining the covenantal basis of missio Dei, Schirrmacher (2017:20) points out that Reformed theologians like Voetius and Herman Witsius have always emphasised that believers and the church compose a part of the covenant that already exists between the Father and the Son.

The covenant of redemption was contracted in eternity past between God the Father and God the Son when they covenanted together for the redemption of the human race, the Father appointing the Son to be the mediator - the Second Adam - whose life would be given for the salvation of the world; and the Son accepting the commission, promising to do the work which the Father had given him and fulfil all righteousness by obeying the law of God.

In Luke 22:29 Jesus promises that He will make the disciples

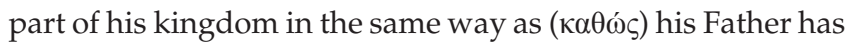
done for him. $\Delta 1 \alpha \tau i \theta \varepsilon \mu \alpha$ (from the verb $\delta 1 \alpha \tau^{\prime} \theta \eta \mu \mathrm{u}$ ) can mean: 'to issue a decree' or 'to make a covenant' (Ac 3:25; Heb 8:10; 10:16).

This lays a New Testament exegetical foundation for the reformed understanding of the covenant of redemption. In the eternal plan of God, it was decreed and covenanted that:

- the Father would plan the redemption through election and predestination;

- the Son would provide redemption through his atoning death;

- the Holy Spirit would effect the plan through regenerating and sealing the believers. (Eph 1:3-14) 
Numerous other Scripture passages emphasise the eternal nature of the plan of salvation (Eph 3:11; 2 Th 2:13; 2 Tm 1:9; Ja 2:5; $1 \mathrm{Pt} \mathrm{1:2).} \mathrm{Christ} \mathrm{referred} \mathrm{to} \mathrm{his} \mathrm{coming} \mathrm{as} \mathrm{a}$ commissioning (Jn 5:30, 43; 6:38-40; 17:4-12). Christ is also regarded as the representative of the human race and the Head of a covenant (Rm 5:12-21; 1 Cor 15:22).

To understand missio Dei from a reformed perspective, it is important to see the link between the covenant of redemption and the covenant of grace. The first provides the deepest foundation because by that, God effects the covenant of grace, providing a God-centred motivation and vision for world missions. Based on this understanding of missio Dei in the light of the pactum salutis, we can define missions as follows:

Through Jesus Christ, and by the Holy Spirit, God, for his own glory, will unite people from every tribe, nation, kingdom, and language to worship him forever in the new creation.

Surprisingly, Witsius points out how the pactum salutis was referred to even in Arminius' comments, in his doctoral oration of July 1603, about the relationship between the Father and the Son to be most suitable (Muller 2007:12).

Witsius also notes that Gomarus - a key opponent of Arminius and prominent at the Synod of Dort that produced the Canons - had referenced the doctrine of the pactum salutis in his exegesis of the baptism of Christ, referring to Christ's baptism as sign and seal of the covenant between God and Christ; namely that God would be his God ... [and] he himself was bound to perform obedience'. Witsius also recognises Voetius - who was a young delegate at the synod of Dort - as one of the major formulators of the doctrine of the pactum salutis in the generation immediately before his (Witsius') generation (Muller 2007:13).

Gisbertus Voetius (or Gijsbert Voet) who is generally regarded as the father of Reformed Missional Science (and also one of the main founders of Reformed Church Polity), was a young delegate at the Synod of Dort. Where the Remonstrants accused the Reformers that their emphasis on God's sovereignty suffocates all zeal for missions and church planting, Voetius developed a comprehensive missional theology from the perspectives of the pactum salutis underlying the theology in the Canons of Dort. He was the first Protestant theologian to develop a wide-ranging, contextual Reformational missiology. It was written in Latin with the title De plantationes ecclesarium (regarding the planting - or establishing of churches (Van Andel 1912:70ff.).

He emphasises that mission is based on the concealed council of God as well as on the revealed will of God. God is the Author, nevertheless he also reveals that God calls people and equips them and instructs them to start new churches.

Gomarus, who played a prominent role at the Synod of Dort, was unable to persuade the synod to endorse his supralapsarianism - that is, the idea that God's decree of election preceded the fall of man and contemplated man's fallen state as part of the divine plan of predestination (Elwell 1998).
Although the missio Dei implications of the doctrine of the pactum salutis undergirding the canons are not fully expressed, God's redemption of the cosmos through the saving work of Jesus Christ, applied to the hearts of his people by the Holy Spirit as understood in the doctrine of the pactum salutis, is clear.

This provides a God-centred perspective in missions, which is a rarity in much of contemporary missiological publication, and it sounds almost like a novelty in an anthropocentric society, ecclesio-centric Christendom, and world-revolutionary humanism. Yet it is in perfect harmony with Paul when he writes, 'For of him, and through him, and to him, are all things: to whom be glory forever. Amen' (Rm 11:36; cf. also Peters 1979:4).

Hartenstein (as quoted by Schirrmacher 2017:36) summarises this briefly in the following manner: 'The sending of the Son in order to reconcile the cosmos by the power of the Spirit is the origin and end of missions.'

Mission has its origin in God's eternal being and plan; it has its content in the good news that God is Lord and Redeemer of creation through Jesus Christ. Its goal is the glory of God and is ushering in his kingly rule over all people groups on earth and all of creation. Seen in this way, mission is the midwife of the new creation to be revealed at Christ's parousia, when God's glory and man's freedom from sin and Satan will be complete.

Based on this understanding of missio Dei in the light of the pactum salutis, the Reformed Churches in South Africa defines missions as follows: Reformed mission: God is busy, for the sake of his glory, to:

1. gather and unify, with word and deed, people from every nation and language and people;

2. by equipping the church, through the Holy Spirit;

3. on the basis of Jesus Christ's crucifixion, death and resurrection;

4. to serve and Worship HIM forever in a new creation.

\section{Discussion of missional perspectives in relevant sections of the Canons and its implications for missions}

It is not possible to consider each article of the Canons in one academic journal article. Only some key missional perspectives will be derived from the canons and the practical relevance of it for the missions ecclesiae that flows from the missio Dei can be discussed.

\section{The proclamation of the gospel starts with an explanation of sin}

Article 1 of the First Head of Doctrine of the Canons starts by stating that all people have sinned in Adam and so are subject to the curse and eternal death. God would not have been unfair to anyone, if He had left everyone in sin and under 
the curse, and had willed to damn them all on account of sin. The Apostle teaches this: 'The whole world is guilty under the condemnation of God'; 'all have sinned and fallen short of the glory of God'; and 'the wages of sin is death' (Rm 3:19, $23 ; 6: 23){ }^{4}$

In mission and evangelism effective proclamation of the gospel must go hand in hand with leading people to understand the depths of sin. When the Holy Spirit convicts people of this fact, they will no longer pity themselves as poor, innocent victims of something over which they had no control, but see their own personal guilt before God.

Pronk (1999) formulates as follows:

When we feel the plague of our hearts - the enmity against God, the power of sin, and bondage to our lusts - we see this not as something that has come over us without our fault or consent, but we realize that we are responsible and we have to give an account to God. (p. 17)

Ferguson (2009) points out how Jesus in his confrontation with the Jews according to the Gospel of John (8:34), pointed out the sinful effects of enslavement to the devil that effects every dimension of our lives:

- Our minds. We do not think clearly; We may be well educated and have high IQs. But that is no guarantee that we think clearly about spiritual things.

- Our desires. When we are on our own and at our most honest, we recognize that we are not masters of our desires. We try to master them. We have a moral consciousness that says, 'You must get these things under control.' But inwardly we are out of control. There is a world within us over which we have no mastery.

- Our wills. They are in bondage to sin. 'Oh yes,' we say, 'this message about being right with God - I will come to it another day. That is my decision and I can make it whenever I want.' The truth, however, is that we cannot think clearly about or desire Christ by our own unaided decision. Why not? We cannot respond to the good news of the gospel until we want Christ, and we cannot want Christ simply by a decision we can take at any moment we choose. We cannot say to our will, 'Will, will to belong to the Lord!' It is beyond our powers to do that. No one can will the will to will what it will not will! Only God's grace can. (p. 4)

This has vital implications for integral mission seen as the reversal of sin and its consequences, and the restoration of God's order in all of creation including God's intent for humans to be his image bearers in all aspects of their lives. Through the transforming grace of the Holy Spirit, working powerfully through the gospel coming to people in word and deed, such transformation will make people worshippers of God and more fully human.

Doing mission work from the presupposition of the reality of total depravity, helps missionaries to understand that 4.This article uses the more simple translation of Godfrey (2019:85-179). transformation of individuals and communities must go much deeper than merely changing conditions of poor socialisation, releasing untapped potential in people and communities, or changing environmental conditions that are often the prime focus of contemporary social gospel approaches in missions and humanistic community development projects. Presuppositions that merely focus on superficial transformation in community development, are in danger of failing to be holistic, comprehensive and long lasting. An unbiblical and limited understanding of the causes of people's problems will misdirect approaches to community development.

\section{Salvation history in the Canons}

The following opening sections of the first chapter provide a brief overview of salvation history, moving from the fall via the gospel of Jesus Christ in John 3:16 (1.2) to the preaching of this gospel (1.3), and its effect in belief and unbelief (1.4). Only thereafter do the Canons move on to God's eternal decree (1.5-6; cf. Huijgen 2018:119).

This makes it clear that the thrust of the whole first Head of Doctrine was not, as proponents of (the early 20th century) TULIP arrangement suggests, 'total depravity'. The real focus is that people are saved by divine grace through faith that is a gift of God and not something earned by believers.

We need to keep in mind that the Arminians, against perceived determinism and supralasirianism in the Reformed Churches, were teaching that election is conditioned upon foreseen faith (fides praevisa). If that is true, grace is no longer grace, since according to the Remonstrant scheme, our faith is imputed to us and is the product, to some degree, of our cooperation with grace.

When article 2 immediately moves from human lostness to the love of God, the gift of the Son, and the promise that everyone who believes in Jesus will be saved and have eternal life, the core of the gospel and (in the words of Haak 2016:23) the heartbeat of mission is introduced.

Because it is a message for all who hear, it leads to article 3 stating that God mercifully sends messengers of this most joyful news to those He will and when He will, so that people may be brought to faith.

This is stated crystal clear in article 5 of chapter 2, that is called the magna carta of missions (Hoekema 1972:214) and 'glorious mission minded' (Haak 2016:24):

The Call to Believe Is to Be Preached to Everyone The promise of the gospel is that whoever believes in Christ crucified shall not perish but shall have eternal life. This promise along with the command to repent and believe ought to be announced and proclaimed generally and indiscriminately to all peoples and humans to whom God, according to His good pleasure, sends the gospel. (2019:116-117, [Translation of Godfrey])

This article addresses the preaching of the gospel. This preaching must declare that all who believe in Jesus will have 
eternal life. The promise of life in Christ as well as the command to repent of sins and believe in Jesus is to be proclaimed to all. Here is an unequivocal call to preach Christ to all. The only limitation noted here is God's providential ordering of history. Throughout history, God has sent preachers to some places by opening doors and not sent them to others. But wherever God makes it possible, the gospel must be preached to all. What is noteworthy here is that no explicit link is made. (2019:116-117, [translation of Godfrey])

The views of John Calvin can be detected in these formulations when he writes: The Father will show 'not only in one corner, what true religion is ... but He will send forth his voice to the extreme limits of the earth' (Calvin $1950 \mathrm{ff}$; Commentary on Mi 4:3). Jesus came 'to extend his grace over all the world' (Calvin 1983:161-172). The Holy Spirit descended to 'reach all the ends and extremities of the world' (Calvin $1950 \mathrm{ff} . ;$ Commentary on Acts 2:1-4). In short, Calvin firmly believed that an innumerable offspring 'who shall be spread over the whole earth' will be born to Christ (Calvin 1950 ff.; Commentary on Ps 110:3).

Note that this article clearly states, people are called to repentance and faith in Christ crucified. The accusation of Calvinism, teaching determinism, is refuted.

But the article also makes it clear that missionaries will not reach every individual but only those to whom God sends them.

\section{In this regard Godfrey (2019) rightly states:}

The implicit point here is that God has always restricted his grace in various ways. It is restricted to some in predestination, but it is also restricted to some in the providence of God, which sends preachers to some and not others. (p. 87)

The views of Calvin can also be detected in this regard when he teaches that the ordinary method of 'collecting a church' is by the outward voice of men:

for though God might bring each person to himself by a secret influence, yet He employs the agency of men, that He may awaken in them an anxiety about the salvation of each other. (Calvin 1950 ff.: Commentary on Isaiah 2:3)

He goes so far as to say, 'Nothing retards so much the progress of Christ's kingdom as the paucity of ministers' (Calvin 1858:4, 263). Still, no human effort has the final word. It is the Lord, says Calvin, who 'causes the voice of the gospel to resound not only in one place, but far and wide through the whole world' (Calvin 1950 ff.: Commentary on Isaiah 49:2).

When the fruit of unbelief is contrasted with the fruit of faith in article 1, 4 it is clearly stated that the anger of God remains on those who do not believe this gospel. In the same time, the sure promise to believers is reiterated that those who receive it and embrace Jesus the Saviour with a true and living faith, are freed by him both from the anger of God and from destruction. This also affirms the crucial importance of missions, since it clearly states that the wrath of God remains on those who do not believe the gospel, but that those who accept the gospel will be saved.
Preaching to people who have never heard of Christ should also proclaim the promises of the gospel and then summons hearers to repent and believe. One of the best examples of contextualisation with the aim to connect with and confront pagans, is Paul's preaching on the Areopagus in Athens (Ac 17:22-34). His sermon builds up to the climax of verse 30-31:

The times of ignorance God over-looked, but now He commands all people everywhere to repent, because He has fixed a day on which He will judge the world in righteousness by a man whom He has appointed; and of this He has given assurance to all by raising him from the dead.

The goal of preaching is to make Jesus Christ present and not simply to teach new religious doctrine to be affirmed and understood. It announces what God is doing through Jesus by the Spirit. The message itself is the power of God to transform lives. ( $\operatorname{Rm~1:16;~} 1$ Cor 1:18, 24; 2:4) Where this everlasting gospel of salvation and judgement, of forgiveness and condemnation, is faithfully preached, Christ himself is at work opening and closing the entrance to the kingdom of heaven (Goheen 2011:212).

\section{Practical implications for faithful missional preaching}

Where unbelievers come under the preaching of missionaries, but they do not hear in it the gospel and are not called to repentance and faith through the warning of the judgement of God (Jn 3:36). an opportunity to open the doors of heaven for them has been missed, and their blood is on the hands of the preacher (Ezk 33:7-9; Ac 20:26-27).

Preaching that fails to invite people to embody a different story of the world than the one offered by the dominant culture, will leave them vulnerable to the idolatrous stories of the culture.

\section{Election a stumbling-block, or an encouragement for missions?}

The accusation is sometimes made, that the lack of missional vision and activity is caused by the firm Calvinistic confession of predestination or election of the saints from eternity.

We note that faith, which is portrayed elsewhere in the Canons as a gift of God, is described in Paragraph 5 of chapter 2 as the responsibility of man. The article also reminds that the promise of the gospel must be accompanied by the command to repent and believe, since without faith and repentance no one will be saved. One could hardly ask for a clearer statement of the missionary task of the church. It is not merely said that the gospel message may be brought to all, but that it ought to be proclaimed to all.

When the efficacy of the death of Christ is dealt with in II:8, it is clear that when the gospel message is faithfully brought, missionaries may be sure that all those who are God's true people (or, to use the language of the Canons, who belong to God's elect) will respond in faith and obedience. Thus far 
from being a hindrance to missions, the canons provide a powerful incentive for missions. The missionary knows that his work is not in vain, since Jesus, speaking through the preacher will usher in his kingdom.

The next article, II:9, expresses the confidence that missionaries may have the confidence that the purpose of missions will certainly be fulfilled: 'Hence we know that in due time the elect will be gathered together into one. Hence, we also know that there will always be a church of believers founded on the blood of Christ. ...' The first sentence of the article, coming before what was just quoted, asserts that the counsel of God to save his people has been fulfilled from the beginning of the world to the present time and will continue to be fulfilled from now on.

Although not given in the article, a biblical reference, one may think of the words of Jesus in John 10:1-16. The picture given in John 10 is of Jesus as great Shepherd who sovereignly saves his sheep. The Father gives the sheep to him. He then dies for them, he calls them by the name - he gives them eternal life, and he keeps them safe forever.

Piper (2008) refers to John Alexander, a former president of InterVarsity, saying in a Q\&A at the Urbana Missions Conference:

At the beginning of my missionary career I said that if predestination were true, I could not be a missionary. Now after 20 years of struggling with the hardness of the human heart, I say I could never be a missionary unless I believed in the doctrine of predestination. (p. 67)

\section{The uniqueness of Christ in missions and the Canons}

In the third and fourth heads of doctrine, the corruption of man, his conversion to God, and the way this conversion occurs, is explained.

Man's utter inability to return to God in his own strength, as described in article 3 , ought to be one of the basic presuppositions in missions.

Article 4 decisively rejects the idea that man can arrive at a saving knowledge of God by making good use of 'the light of nature'.

Article 6 affirms the uniqueness of the Christian religion, and the fact that there is only one way to be saved:

What, therefore, neither the light of nature nor the law can do, God does by the power of the Holy Spirit, through the word or ministry of reconciliation, which is the gospel of the Messiah, by which it has pleased God to save men who believe, both under the Old and under the New Testament.

These articles are of basic importance for a theology of missions. It has implications for the rejection of inclusivistic and pluralistic approaches in missions for reformed missionaries.
Horton (2011b) points out how relevant the evangelical reformed beliefs have become in the Western world in the light of the fact that:

Seventy percent of American adults endorse the statement, 'Many religions can lead to eternal life' and that according to a 2008 Pew Forum study; more than half (57 percent) of those selfidentified as members of evangelical Protestant churches agreed. $^{5}$ (pp. 92-93)

\section{The importance of prayer in missions}

In article 15 in chapter 3 and 4 it is stated: 'As for those not yet called, we should pray to God who calls things that are not as if they were'.

These words stress the duty of missionaries as well as their sending churches and organisations to pray for unbelievers that the Lord would be pleased to give the gift of faith.

The first time the New Testament speaks about mission, it firstly shows us the heart of Jesus. Then his command is to pray!

When He saw the crowds, He had compassion for them, because they were harassed and helpless, like sheep without a shepherd. Then He said to his disciples, 'The harvest is plentiful, but the laborers are few; therefore, pray earnestly to the Lord of the harvest to send out laborers into his harvest'. (Mt 9:36-38 ESV)

The word compassion in this text means, literally, to be moved in one's stomach with pity.

Such compassion stirs up prayer and intercession. Praying for missions is not a fringe activity from God's point of view. By praying, Christians become co-workers in God's great purposes. When Paul writes about his missional struggles to the church in Rome, he pleads with them: 'I appeal to you, brothers, by our Lord Jesus Christ and by the love of the Spirit, to strive together with me in your prayers to God on my behalf' (Rm 15:30 ESV). Prayer gives Christians the opportunity to make a vast difference in this world. Your prayers are vital.

In a real Calvinistic Reformed Church, prayer and intercession ought to be of a very high priority. One of the key aspects of the reformed faith as expressed in the Canons of Dort, is that Christians acknowledge with their whole hearts that the church flows from the grace of God alone (sola gratia).

It implies to acknowledge that all human efforts in sowing the gospel is of no use if the Holy Spirit does not change hearts and regenerate sinners by drawing them to Christ and enables them to embrace the Lord Jesus Christ as Saviour and Lord. Continuous prayer and intercession acknowledge that everything comes from God alone. The more a church

5. It is not possible within the delimitation of the scope of this article and the required lenth, to discuss the debates about pluralistic, inclusivistic and exclusivistic lenpth, to discuss the debates about pluralistic, inclusivistic and exclusivistic approaches to missions. The following authors have thoroughly discussed thes various approaches: Carson (1996); Fernando (1995); Geivett and Phillips (1995); Horton (2011); House and Thornbury (2000); McLaren (2004); Morgan and Peterson (2008); Moo (1991); Partridge (1998); Strange (2002); Wright (1997); Geisler (1999). 
becomes really reformed - embracing the concept of grace alone - the more such a church will become a praying church.

When prayer and intercession for missions has a low priority in the ministry of a local church, it is often a reflection of a superficial knowledge of what the Bible and the Reformed Confessions really teaches about prayer. Therefore, it is important to review basic key aspects of what the Bible teaches about prayer and the importance of intercession and to preach and teach about it.

\section{Implications of belief in the perseverance of the saints for missions}

The fifth and final chapter deals with the perseverance of the saints. This provides comfort for the (new) believer being tempted by many trials as well as for the missionary who have anxieties about the long-term fruit of his hard work. God will sustain his elect up till the end of their lives and till the end of times. The outcomes of mission work may sometimes be hidden for a long period but will be manifested in the eschaton with the second coming of Christ. The doctrine of the perseverance of the saints humbles missionaries, because from beginning till end it is God's mission to save his elect in Christ, and gather them as the glorious Bride of Christ, as Paul states in 1 Corinthians 3:6:

$$
\begin{aligned}
& \text { I planted the seed } \\
& \text { Apollos watered it, } \\
& \text { but God made it grow. (ESV) }
\end{aligned}
$$

The comfort for the missionary as well as for new believers, is the firm conviction, based on God's faithfulness, that the one who had begun the good work of a new creation in believers' lives, would bring it to completion on the day of Christ Jesus (Phlp 1:6; cf. also Jud 24-25).

But this chapter clearly states the belief that sin remains in the regenerate (article 1), and they must constantly pursue sanctification (article 2), knowing that even the best works that Christ's people perform in this life, are marred by sin until Jesus returns.

Article 3 therefore makes it clear that Christians persevere in their faith only because God is faithful to his plans and promises and is merciful. Despite their sins, Jesus Christ intercedes for them (Lk 22:31-32).

In the explanation that regenerate may still fall into serious sins; article 4 refers to the examples of David and Peter. Adultery, murder, and apostasy - some of the very worst sins - are possible for the Christian. Yet even such sins cannot separate them from the love of God for us in Christ Jesus. As Godfrey (2019) states:

This means that even in the midst of the most calamitous falls into sin, there is hope and comfort when we turn to God. The Holy Spirit remains with us even when grieved or apparently quenched. When we speak of the perseverance of the saints, we recognize the reality of all the struggles in the lives of the saints, but also that they ultimately move toward God. This perseverance occurs because God is always active preserving his own. The perseverance of the saints is the fruit of the preservation of the saints. (p. 158)

The fact that sanctification is stated so clearly in this section of the Canons, makes it clear that 'easy believism' (Monergism 2019), teaching that all that is required of one to be saved is that he believes the facts of the gospel and verbalises those facts to God in prayer, but that it is not necessary to repent and to be changed in lifestyle, is not at all in line with the Canons of Dort. Bennett (1999:28) calls this kind of evangelistic strategy 'the greatest heresy plaguing Southern Baptists today'.

Many church leaders are telling people, 'believe in yourself', and are preaching a gospel that is more concerned with fulfilling our desires than God's. Such teaching hinders people falling unreservedly into the arms of the Saviour, in whom they will find their only confidence.

Believers have the responsibility to 'go on to maturity' (Heb 6:1). But according to the canons, this follows after regeneration and conversion. Full assurance is the product of drawing:

near with a true heart in full assurance of faith, with our hearts sprinkled clean from an evil conscience and our bodies washed with pure water. Let us hold fast the confession of our hope without wavering, for He who promised is faithful. (Heb 10:22-23)

\section{Horton (2011b:183) explains:}

Why is it that in some churches we see the same people walking down the aisle week after week? Perhaps it is because we are looking to something we can do, or have done, to secure the kind of assurance we need. But we can't trust our feelings or our abilities of either will or effort, so we're left with having to trust in the ability of God, 'who is able to keep you from falling'. (Jud 24)

Missionaries who firmly believe in the doctrine of the perseverance of the saints, as expressed in the Canons of Dort, and who have established churches, will be helped to avoid the danger of paternalism. They will have the vision to disciple new believers towards maturity and develop indigenous leaders, and eventually have the faith and courage to allow a young church to become a self-governing church, so that paternalism may lead to real partnership.

Concerning paternalism, Shaw (1997) warned that though Henry Venn had insisted early in the 1800s that African churches should become self-governing, self-supporting, and self-propagating churches, by the end of the century, this vision had been lost. Bishop Samuel Ajayi Crowther of Nigeria, the first African bishop of the Anglican church, pointed out that white missionaries undermined his authority and wrongly discredited his work.

It is interesting that a new realisation of acknowledging the sovereignty of God in missions at the Urbana missions 
conference, brought some balance in dealing with paternalism. Huneycutt (2011) states:

Students have heard much about colonialism, paternalism, western imperialism (religious as well as political), failures of mission policies, racism in missions, superiority attitudes of missionaries, ad infinitum. ... There comes a time when negativism can no longer produce positive results. In my opinion, we have reached that point in missions. ... Therefore, the planners for Urbana '73 ... have decided to take a positive approach. ... We want to sound a forward-looking note of hope based on the sovereignty of God as the Lord of history who will fulfill all of his purposes. (p. 76, [author's own italics])

\section{Conclusion}

Although a complete theology and strategy of missions cannot be found in the Canons of Dort, we conclude that the Canons of Dort and its underlying theology certainly do provide perspectives on the missionary focus of Scriptures. The deeply concern that men be reconciled to God, God's purpose from eternity to bring about this reconciliation, and that this purpose is being fulfilled in the gathering of the elect by his Word and Spirit from the beginning of the world to the end of time, can be deducted. Therefore, we can agree with Hoekema (1972:220), that the main focus of the Canons, is the missio Dei: God's redemption of the cosmos through Christ.

It was not the intention of the Canons of Dort to give full expression to the missionary implications of the teaching presented, but one may ask: Is it really the goal of confessions to spell out all the practical missions and ministry implications of doctrine?

The strong missionary theology in the doctrine of the sovereign work of God in saving his people, as stressed in the Canons of Dort, does provide courage and hope and inspiration to contemporary missionaries to persevere in their calling.

\section{Acknowledgement Competing interest}

The author declares that no competing interest exists.

\section{Author contributions}

I declare that I am the sole author of this research article.

\section{Funding}

This research received no specific grant from any funding agency in the public, commercial, or not-for-profit sectors.

\section{Data availability statement}

Data sharing is not applicable to this article as no new data were created or analysed in this study.

\section{Disclaimer}

The views and opinions expressed in this article are those of the authors and do not necessarily reflect the official policy or position of any affiliated agency of the authors.

\section{Ethical consideration}

This article followed all ethical standards for carrying out research without direct contact with human or animal subjects.

\section{References}

Bennett, B., 1999, 'The greatest heresy plaguing southern Baptists today', Faith and Mission 17(2), 28-73.

Bratcher, D.R., 2018, The five articles of the Remonstrants (1610), viewed 15 April 2019, from http://www.crivoice.org/creedremonstrants.html.

Bredenhof, W., 2014, Outward looking church: Current craze or Christ's commission? (2), viewed 15 April 2019, from https://yinkahdinay.wordpress.com/tag/canonsof-dort/.

Buys, P.J., 22(87), a1328. https://doi.org/10.4102/ids.v22i87.1328

Calvin, J. 1950 ff., Commentaries of John Calvin, Eerdmans, Grand Rapids, MI, Software version on $C D$ being used.

Calvin, J., 1858, Letters of John Calvin, Ed. by J. Bonnet, Presbyterian Board of Publication., Philadelphia.

Calvin, J., 1983b, Sermon on the epistles of S. Paul to Timothy and Titus, trans., L.T. (repr.), Banner of Truth Trust, Edinburgh

Carson, D.A., 1996, The gagging of God: Christianity confronts pluralism, Zondervan, Grand Rapids, MI.

Clark, R.S., 2018, The Canons of Dort (1): Introduction and background, viewed 27 April 2019, from https://www.agradio.org/the-canons-of-dort-1-introductionand-background.html.

Coetzee, C.F.C., 2018, 'What can we learn from Dordrecht for a possible authentic Confessio Africana?', In die Skriflig 52(2), a2376. https://doi.org/10.4102/ids. v52i 2.2376

Conn, H.M. (ed.) 1976, Theological perspectives on church growth, Presbyterian \& Reformed Pub. Co., Philipsburg.

De Jong, P.E. (ed.), 2008, Crisis in the reformed churches: Essays in commemoration of the Great Synod of Dort, Reformed Fellowship, Grandville.

Elwell, W.A., 1998, In biographical entries from Evangelical dictionary of theology, electronic edn., vol. 1, Book House, Grand Rapids, MI.

Engelsma, D., 1980, Hyper-Calvinism and the call of the gospel, Reformed Free Publishing Association, Grand Rapids, MI.

Faber, J., Meijerink, H.J., Trimp, C. \& Zomer, G., 1965, De schat van Christus' bruid, Oosterbaan \& Le Cointre, Goes.

Ferguson, S.B., 2009, By grace alone: How the grace of God amazes me, Reformation Trust Publishing, Kindle edn.

Fernando, A., 1995, The supremacy of Christ, Crossway, Wheaton.

Fuller, A., 1837, The gospel worthy of all acceptation; or, The duty of sinners to believe in Jesus Christ, American Doctrinal Tract Society, Boston, MA.

Geisler, N.L., 1999, 'Pluralism, religious', in N. Geisler (ed.), Baker encyclopedia of Christian apologetics, p. 598, Baker Books, Grand Rapids.

Godfrey, W.R., 2019, Saving the reformation: The pastoral theology of the Canons of Dort, Reformation Trust Publishing, Kindle edn.

Geivett, R.D. \& Phillips, G.W., 1995, 'A particularist view: An evidentialist approach', in D.L. Okholm \& T.R. Phillips (eds.), Four views on salvation in a pluralistic world, pp. 211-259, Zondervan, Grand Rapids, MI.

Goheen, M.W., 2011, A light to the nations: The missional church and the biblical story Baker, Grand Rapids, MI.

Haak, C.J., 2016, Reformed means mission: The missionary flavor of the reformed confessions, Unpublished class lectures.

Hoekema, A.A., 1972, 'The missionary focus of the Canons of Dort', Calvin Theological Journal 7(2), 209-220, November.

Horton, M. 2011a, The gospel commission: Recovering God's strategy for making disciples, Baker Books Grand Rapids, MI.

Horton, M., 2011b, Putting amazing back into grace: Embracing the heart of the gospel, Baker, Grand Rapids MI.

House, P.R. \& Thornbury, G.A. (eds.), 2000, Who will be saved?: Defending the biblical understanding of God, salvation, and evangelism, Crossway, Wheaton.

Huneycutt, Y.W., 2011, 'Launching a movement: A history of the perspectives course', in B. Snodderly \& A.S. Moreau (eds.), Evangelical and frontier mission perspectives on the global progress of the gospel, viewed 27 April 2019, from http://www. ocms.ac.uk/regnum/downloads/Evangelical\%20and\%20Frontier\%20Missionfinal-WM.pdf. 
Huijgen, A., 2018, 'The theology of the Canons of Dort: A reassessment after four hundred years', Unio cum Christo 4(2), 111-128. https://doi.org/10.35285/ hundred years',
ucc4.2.2018.art7

Jackson, S.M., (ed.), 1914, In the new Schaff-Herzog encyclopedia of religious knowledge: Embracing biblical, historical, doctrinal, and practical theology and biblical, theological, and ecclesiastical biography from the earliest times to the present day, vol. 9, Funk \& Wagnalls, New York.

Maclean, D.J., 2010, 'James Durham (1622-1658) and the free offer of the gospel', Puritan Reformed Journal 2(1), 92-119.

McDonald, S., 2018, The Canons of Dordt for the church today: Polemics, pastoring, and pulling up TULIPs, viewed 15 April 2019, from https://vimeo.com/291165325.

McLaren, B.A., 2004, GenerousoOrthodoxy: Why I am a missional, evangelical, post/ protestant, liberal/conservative, biblical, charismatic/contemplative, ... emergent, unfinished Christian, Zondervan, Grand Rapids, MI.

Meijerink, H.J., 1965, 'Uit de geschiedenis van het ontstaan der Dordtse Leerregels', in J. Faber, H.J.

Meijerink, C. Trimp \& G. Zomer (eds.), De schat van Christus' bruid, pp. 7-65, Oosterbaan \& Le Cointre, Goes.

Monergism, 2019, What is 'easy-believism'?, viewed 15 April 2019, from https:// www.monergism.com/thethreshold/articles/onsite/qna/easybelieve.html.

Moo, D., 1991, 'Romans 2: Saved apart from the gospel?', in W.V. Crockett \& J.G. Sigountos (eds.), Through no fault of their own?: The fate of those who have never heard, pp. 137-145, Baker, Grand Rapids, MI.

Morgan, C.W. \& Peterson, R.A., 2008, Faith comes by hearing: A response to inclusivism, InterVarsity, Downers Grove, IL.

Müller, K., 1985, Missionstheologie, Reimer, Berlin.

Muller, R.A., 1991, God, creation, and providence in the thought of Jacob Arminius: Sources and directions of scholastic Protestantism in the era of early orthodoxy, Baker, Grand Rapids, MI.

Muller, R.A., 2007, 'Toward the pactum salutis: Locating the origins of a concept', MidAmerica Journal of Theology 18, 11-65.

Partridge, C., 1998, 'Review of uniqueness of Jesus by Chris Wright', Themelios 23(3), 107.

Peters, G.W., 1979, 'Missions in biblical perspective: Perspectives on the church's mission, Part 1', Bibliotheca Sacra 136, 3-15.

Piper, J., 2008, Other sheep that are not of this fold, Lecture given at the Desiring God 2008 Regional Conference, viewed 01 May 2019, from https://www.desiringgod. $\mathrm{org} / \mathrm{messages} /$ other-sheep-that-are-not-of-this-fold.

Praamsma, L., 2008, 'The background of the Arminian controversy (1586-1618)', in P.Y. de Jong (ed.), Crisis in the Reformed churches: Essays in commemoration of the great Synod of Dort, pp. 120-135, Eerdmans, Grand Rapids, MI.
Pronk, C., 1999, Expository sermons on the Canons of Dordt, Free Reformed Publications, St Thomas.

Reformed Churches in South Africa, 2019, Missionary church, viewed 29 April 2019, from https://www.gksa.org.za/emissionerekerk.htm.

Shaw, M., 1997, 'Great white father: After Livingstone opened Africa, Western missionaries moved in by the thousands: Did they hurt or help Africans?' Christian History Magazine, issue 56, Missionary-Explorer in Africa, David Livingstone.

Schirrmacher, T., 2017, Missio Dei: God's missional nature, Theological Commission of the World Evangelical Alliance, vol. 10, Verlag für Kultur und Wissenschaft, Bonn. (World of Theology Series).

Stanglin, K.D., 2019, The Remonstrant perspective and the Synod of Dordt, viewed 17 March 2019, from https://vimeo.com/291163650.

Strange, D., 2002, The possibility of salvation among the unevangelized: An analysis of inclusivism in recent evangelical theology, Paternoster Press, Carlisle.

Stanglin, K.D. \& McCall, T.H., 2012, Jacob Arminius: Theologian of grace, Oxford University Press, Oxford.

Stewart, K.J., 2009, 'Calvinism and missions: The contested relationship revisited', Themelios 34(1), 73-78.

Storey, R., Hyper-Calvinism - Properly defined and thoroughly refuted, viewed 23 June 2018, from www.scribd.com/document/214052737/Hyper-Calvinism-Properlydefined-and-thoroughly-refuted.

Van Andel, H.A., 1912, De zendingsleer van Gisbertus Voetius, Kok, Kampen.

Van der Vyver, G.C.P., 1958, Professor Dirk Postma. 1818-1890, ProRege Pers, Potchefstroom.

Van den Brink, C., 2017, Dordt in contex:. Gereformeerde accenten in katholieke theologie, Groen, Heerenveen.

Van der Waal, 1983, 'Ds. D. Postma en die konflikte insake die verbond', Studia Historia Ecclesiastica 111, 35-58.

Van der Walt, I.J., 1982, 'Evangelisasie: 'n Uitdaging vir die Gereformeerde Kerk' Ongepubliseerde referaat gelewer tydens 'n Evangelisasiekonferensie te Pretoria in Oktober 1982.

Van Ryssen, J.W.J., 1983, Oud Gereformeerde tendense in die Gereformeerde Kerke in Suid-Afrika, Ongepubliseerde referaat gelewer tydens ' $n$ vergadering van die Gereformeerde Teologiese Vereniging van Klassis Vaal Rivier, in besit van die outeur in die handskrif van Van Ryssen.

Veenhof, C., 1995, Prediking en uitverkiezing, Kok, Kampen.

Verboom, W., 2005, De belijdenis van een gebroken kerk, Boekencentrum, Zoetermeer.

Wright, C., 1997, Uniqueness of Jesus, Monarch, Evangelical Alliance, Crowborough. 